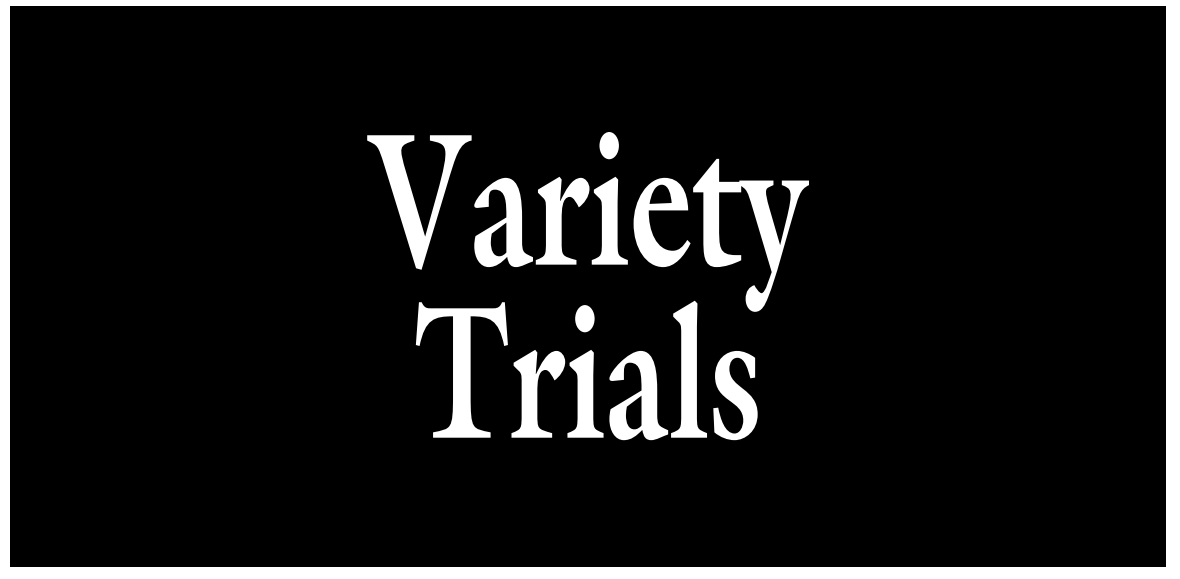

\section{Performance of Broccoli Cultivars in Spring and Fall Evaluations in Pennsylvania}

\author{
Elsa Sánchez ${ }^{1,9}$, Thomas Butzler ${ }^{2}$, Lee Stivers ${ }^{3}$, Robert Pollock ${ }^{4}$, \\ Timothy Elkner ${ }^{5}$, Steven Bogash ${ }^{6,8}$, and William Lamont ${ }^{7}$
}

AdDitional INDEX WORDs. variety trial, Brassica olevacea var. italica, cultivar trial, head quality, broccoli yield

SUMMARY. Recent hypothetical modeling suggests that increasing commercial broccoli (Brassica olevacea var. italica) acreage in the eastern United States has the potential to notably reduce the costs of transportation within the broccoli supply chain. In this region, increasing broccoli acreage will require production improvements. Here, research was conducted to determine the best yielding commercially available cultivars for broccoli production. Eighteen to 19 cultivars of broccoli were evaluated in spring and fall evaluations using diverse production systems during 2014-15 in three locations across Pennsylvania. Data collected included production, yield, and quality attributes. Most interactions between site, year, and cultivar were significant suggesting that environmental conditions influence broccoli yield, quality, and concentration of harvest. Overall, the cultivars evaluated were not different from, Imperial, the standard used, for marketable yield, head diameter, and concentration of harvest within a site year. Blue Wind was consistently the first cultivar harvested, and Avenger and Emerald Jewel the last overall site years and growing seasons. These three cultivars may be good options for extending the growing season.

$\mathrm{B}$ roccoli is a nutrient-rich vegetable containing vitamins, dietary fiber, and antioxidants. It also has been linked to reducing the risk of certain cancers including breast, bladder, and colon cancers (review by Mukherjee and Das, 2009). In the United States, it is grown in all 50 states [U.S. Department of Agriculture (USDA), 2014] and has a farm-gate value of about $\$ 650$ million (USDA, 2011). Most domestic fresh market broccoli is grown on 95,508 acres by 600 farms in California (USDA, 2014) or imported from other countries including Mexico and Canada (Atallah et al., 2012). In the mid-Atlantic regions (Delaware, New Jersey, Maryland, Pennsylvania, West Virginia, and Virginia) fresh-market broccoli is grown on less than 1314 acres by 485 farms. Recent hypothetical modeling suggests that a $30 \%$ increase in broccoli acreage in the eastern United States, including the mid-Atlantic region, has the potential to reduce transportation within the broccoli supply chain by up to $\$ 5$ million a year at 2012 fuel prices and $\$ 12$ million if fuel costs double (Atallah et al., 2012). Increased broccoli production could also be supported by the increase in marketing through local food channels (Low et al., 2015).

In the mid-Atlantic region and the broader eastern United States, increasing broccoli acreage will require production improvements. Broccoli is classified as a hardy cool-season crop with optimum growth occurring between 60 and $65^{\circ} \mathrm{F}$ (Maynard and Hochmuth, 2007) and temperatures above $86^{\circ} \mathrm{F}$ result in head deformity (Björkman and Pearson, 1998). In the mid-Atlantic, it is generally grown as a spring crop, in cooler areas only, or a fall crop (Sánchez et al., 2015); however, expanding the growing season to include summer production could increase the acreage grown. Research has recently been conducted on breeding and evaluating broccoli adapted to high temperatures for summer production (Farnham and Björkman, 201la, 2011b). Currently, in the mid-Atlantic, recommendations for plant populations can reach 32,000 plants/acre (Sánchez et al., 2015) compared with California where plant populations reach 69,636 plants/acre (Ward et al., 2015). Recent research determined that head quality for crown-cut broccoli grown in South Carolina was optimized at a plant population of 72,000 plants/acre (Ward et al., 2015). Determining the best yielding commercially available cultivars is another factor in commercial broccoli production. In this research, 18-19 cultivars of broccoli were evaluated as spring and fall crops during 2014-15 for yield and quality attributes for growers in the mid-Atlantic region.

\section{Materials and methods}

Cultivars evaluated (Table 1 ) were determined based on conversations with growers and seed company representatives and studying seed catalogs. Imperial was considered as the standard cultivar as suggested by growers.

The evaluation consisted of growing spring and/or fall broccoli crops

\begin{tabular}{llll}
\hline $\begin{array}{l}\text { Units } \\
\begin{array}{l}\text { To convert U.S. to SI, } \\
\text { multiply by }\end{array}\end{array}$ & U.S. unit & SI unit & $\begin{array}{l}\text { To convert SI to U.S., } \\
\text { multiply by }\end{array}$ \\
\hline 0.4047 & acre(s) & $\mathrm{ha}$ & 2.4711 \\
102.7902 & acre-inch(es) & $\mathrm{m}^{3}$ & 0.0097 \\
0.3048 & $\mathrm{ft}$ & $\mathrm{m}$ & 3.2808 \\
2.54 & inch(es) & $\mathrm{cm}$ & 0.3937 \\
0.4536 & $\mathrm{lb}$ & $\mathrm{kg}$ & 2.2046 \\
1.1209 & $\mathrm{lb} / \mathrm{acre}$ & $\mathrm{kg} \cdot \mathrm{ha}^{-1}$ & 0.8922 \\
1.1692 & $\mathrm{pt} / \mathrm{acre}$ & $\mathrm{L} \cdot \mathrm{ha}^{-1}$ & 0.8553 \\
$\left({ }^{\circ} \mathrm{F}-32\right) \div 1.8$ & ${ }^{\circ} \mathrm{F}$ & ${ }^{\circ} \mathrm{C}$ & $\left({ }^{\circ} \mathrm{C} \times 1.8\right)+32$ \\
& & &
\end{tabular}

Hortlechnology · December 2016 26(6) 
Table 1. Cultivars and seed sources of spring and fall broccoli crops evaluated at Clinton, Harmony, Pennsylvania Furnace and/or Manheim, PA in 2014-15. The standard was 'Imperial'.

\begin{tabular}{lc}
\hline Cultivar & \multicolumn{1}{c}{ Seed company } \\
\hline Izabal & Rijk Zwann USA, Salinas, CA \\
Tahoe & Bejo Seeds, Inc., Oceano, CA \\
Burney & Seminis Vegetable Seeds, Oxnard, CA \\
Lieutenant & \\
BC1691 & Syngenta, Greensboro, NC \\
Dura Pak 16 & Johnny's Selected Seeds, Winslow, ME \\
Dura Pak 19z & \\
Amadeus & Sakata Seed America, Morgan Hill, CA \\
Blue Wind & \\
Green Gold & \\
Avenger & \\
Expo & \\
Gypsy & \\
Emerald Jewel & \\
Emerald Crown & \\
Green Magic & \\
Diplomat & \\
Imperial & Harris Moran, Davis, CA \\
Luna &
\end{tabular}

${ }^{\mathrm{z}}$ Only evaluated in Spring 2014-15.

in three regions of Pennsylvania: in southwestern Pennsylvania at Janoski's Farm and Greenhouse in Clinton [Fall crop 2014 (lat. $40^{\circ} 29^{\prime} 29.97$ "N, long. $\left.\left.80^{\circ} 19^{\prime} 54.18^{\prime \prime} \mathrm{W}\right)\right]$ and Soergel's Orchard in Harmony [Fall crop 2015 (lat. $40^{\circ} 36^{\prime} 50.22^{\prime \prime} \mathrm{N}$, long, $\left.80^{\circ} 05^{\prime} 32.73^{\prime \prime} \mathrm{W}\right)$ ]; in central Pennsylvania at Pennsylvania State University's Russell E. Larson Research

\footnotetext{
We wish to acknowledge the Pennsylvania Vegetable Research and Marketing Board for funding this project. We thank our on-farm collaborators at Janoski's Farm and Greenhouse and Soergel's Orchard as well as Seedway LLC and Johnny's Selected Seeds for their generous donation of seeds used in this study. We also thank our families for their support.

Use of trade names does not imply endorsement of the products named or criticism of similar ones not named.

${ }^{1}$ Associate Professor, Department of Plant Science, The Pennsylvania State University, University Park, PA 16802

${ }^{2}$ Senior Extension Educator, Penn State Extension, 47 Cooperation Lane, Mill Hall, PA 17751

${ }^{3}$ Senior Extension Educator, Penn State Extension, 100 West Beau Street, Suite 601, Washington, PA 15301

${ }^{4}$ Extension Educator, Penn State Extension, 827 Water Street, PA, 15701

${ }^{5}$ Senior Extension Educator, Penn State Extension, 1383 Arcadia Road, Room 140, Lancaster, PA 17601

${ }^{6}$ Associate Extension Educator, Penn State Extension, 181 Franklin Farms Lane, Chambersburg, PA 17202

${ }^{7}$ Professor, Department of Plant Science, The Pennsylvania State University, University Park, PA 16802

${ }^{8}$ Current address: ISP Technologies, Newville, PA 17241.

${ }^{9}$ Corresponding author. E-mail: ess11@psu.edu.

doi: 10.21273/HORTTECH03519-16
}

flat ground with a single drip irrigation line (T-Tape model 508-12-450; John Deere, Moline, IL) placed on the top of the middle of the row. Plasticulture systems consisted of raised beds, a single line of drip tape on the top of the bed and black embossed polyethylene mulch (Sigma Plastic Groups, Allentown, PA). Planting date, spacing, and plant population varied by year, site, and season (Table 2).

At all sites, drip irrigation was used to supplement rainfall to supply 1 to 1.5 acre-inches of water each week. Pests and weeds were managed following recommendations in the Commercial Vegetable Production Recommendation guide for Pennsylvania (Sánchez et al., 2014). Fertility regimes are listed in Table 2.

Single heads were harvested at maturity when beads (flower buds) were tight and dark green. Stalks were cut to 5 inches long from the top of the head in the central and southeastern sites in 2014 and from the base of the head in 2015 . Stalks were cut to 5 inches long from the base of the head in the southwestern site in both study years. In the southwestern sites, harvest occurred 8 Sept. to 7 Oct. 2014 and 14 Sept. to 13 Oct. 2015 for the fall crops. At the central site, harvest occurred 3 July to 20 Aug. 2014 and 9 July to 15 Aug. 2015 for the spring crops. At the southeastern site, harvest occurred I July to 1 Aug. 2014 and 24 June to 27 July 2015 for the spring crops, and 8 Sept. to 23 Oct. 2014 and 11 Sep. to 29 Oct. 2015 for the fall crops. At all sites, harvested heads were categorized as marketable or unmarketable, counted, and weighed. In addition, head diameter was determined for marketable heads. Heads that were overmature or had diseased beads were graded as unmarketable.

Plots consisting of a minimum of 12 plants of each cultivar were arranged in a randomized complete block design with each cultivar replicated four times. Data were collected from 10 plants per plot and averaged. All data were pooled by site and year and analyzed using the GLIMMIX procedure in SAS (version 9.2; SAS Institute, Cary, NC). When probability values were less than or equal to 0.05 , means were separated using the slice option to perform Tukey's multiple comparison test.

\section{Results}

Most interactions between plants were planted into a bare ground or plasticulture systems (Table 2). Bare ground systems consisted of site, year, and cultivar were significant (Table 3 ) suggesting that 


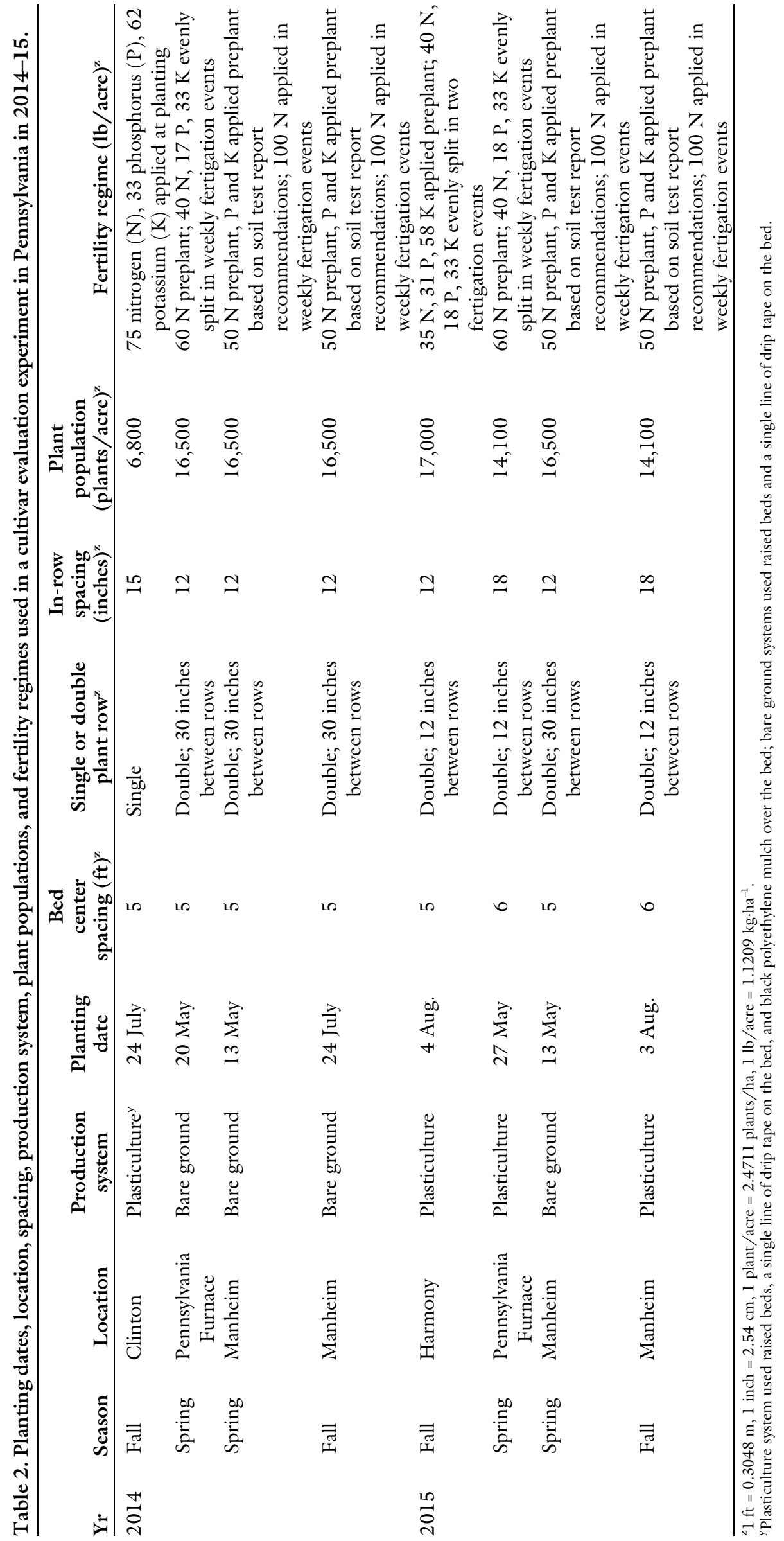




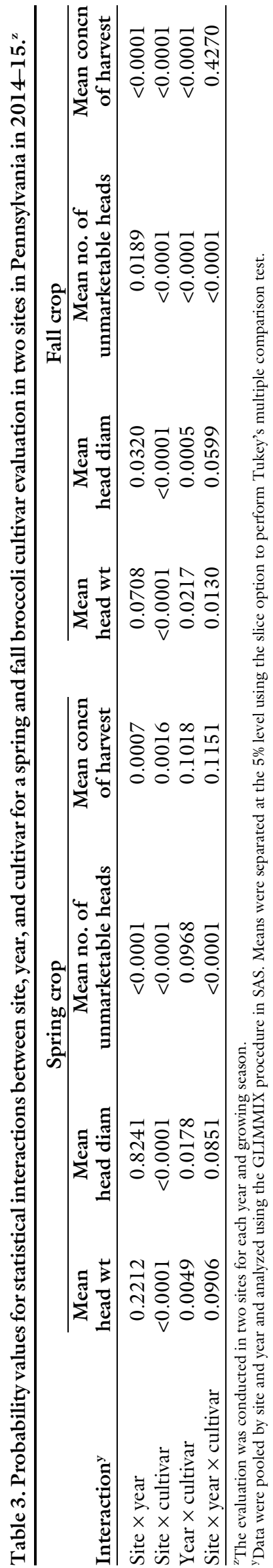

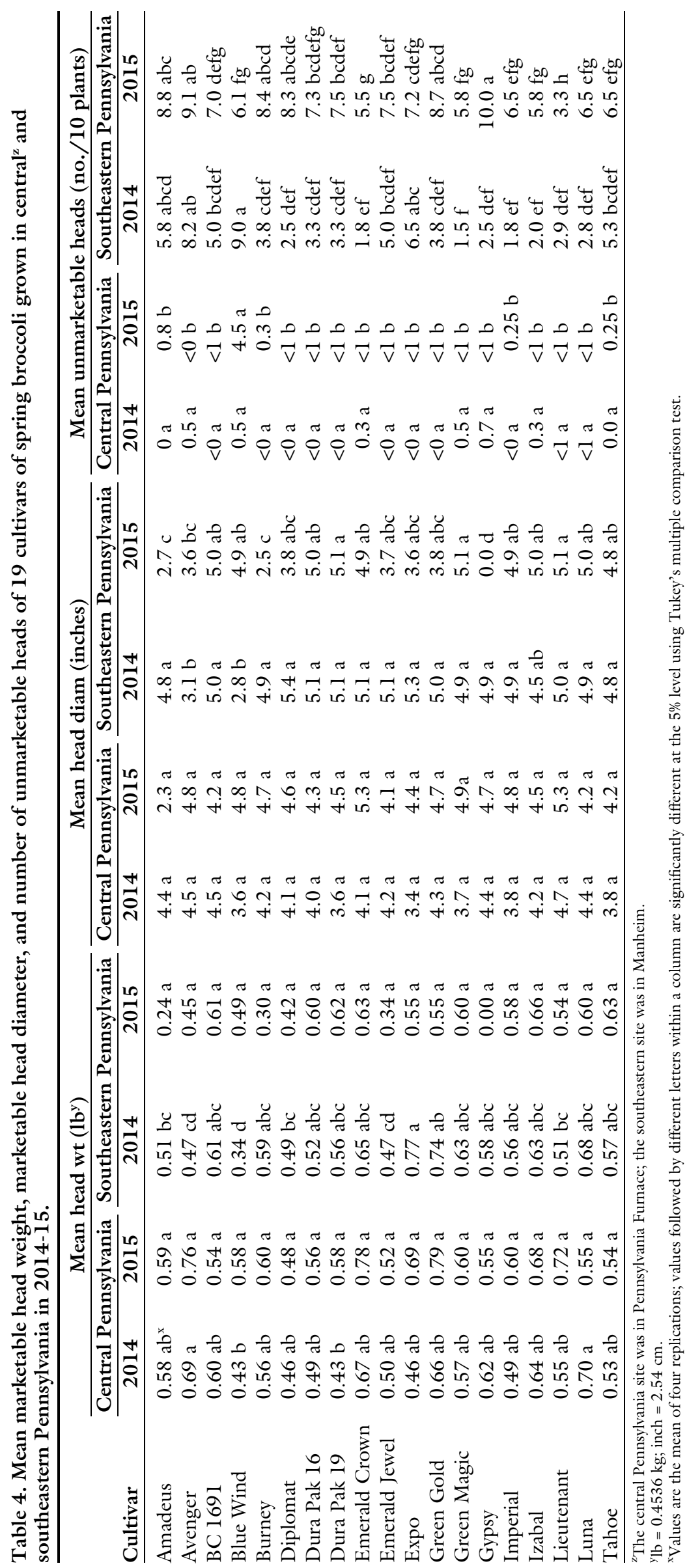

Hortlechnology • December 2016 26(6) 
environmental conditions influence broccoli yield, quality, and concentration of harvest.

SPRING Crop. Mean head weight of 'Imperial' was between 0.49 and $0.60 \mathrm{lb}$, which was not different from most cultivars within a site year (Table 4 ). In fact, the only difference was in 2014 at the southeastern site where 'Blue Wind' heads weighed less at $0.34 \mathrm{lb}$. For most site years, cultivars with the heaviest heads included Avenger, Emerald Crown, Expo, and Green Gold; Blue Wind and Diplomat tended to have the lightest heads.

Mean diameter of 'Imperial' heads was between 3.8 and 4.9 inches, which was not different than all other cultivars at the central location (Table 4). In 2014, at the southeastern site, 'Avenger' and 'Blue Wind' heads had smaller diameters of 3.1 and 2.8 inches, respectively. In 2015, 'Amadeus' and 'Burney' heads had smaller diameters of 2.7 and 2.5 inches, respectively. All 'Gypsy' heads were unmarketable and therefore diameter was recorded as 0.0 .

Mean number of unmarketable (out of 10) 'Imperial' heads was 0.0 to 6.5 (Table 4) which was not different than most other cultivars within a site year. In 2015, in the central site, 'Blue Wind' produced 4.5 unmarketable heads which was more than 'Imperial'. In 2014, at the southeastern site, 'Amadeus', 'Avenger', 'Blue Wind' and 'Expo' produced more unmarketable heads than 'Imperial'. In 2015, at the southeastern site, 'Gypsy', 'Avenger', 'Amadeus', 'Green Gold' and 'Burney' produced more unmarketable heads than 'Imperial' primarily due to yellow beads and loose heads which may be related to higher temperatures. Additionally, 'Lieutenant' produced fewer unmarketable heads than 'Imperial'. The number of unmarketable heads was higher at the southeastern site compared to the central site overall.

Mean concentration of harvest was 1.0 to $15.0 \mathrm{~d}$. depending on cultivar and was not different between cultivars within a site year (Table 5 ). 'Blue Wind' consistently was the earliest to reach maturity in both years and sites relative to the other cultivars. 'Amadeus', 'Burney', 'Green Gold', 'Gypsy', 'Imperial', and 'Lieutenant' were consistently harvested midseason and 'Avenger', 'Dura Pak 19', 'Emerald Jewel', and 'Expo' late season (Table 5).

FALl Crop. Mean head weight for 'Imperial' was between 0.59 and $1.09 \mathrm{lb}$,

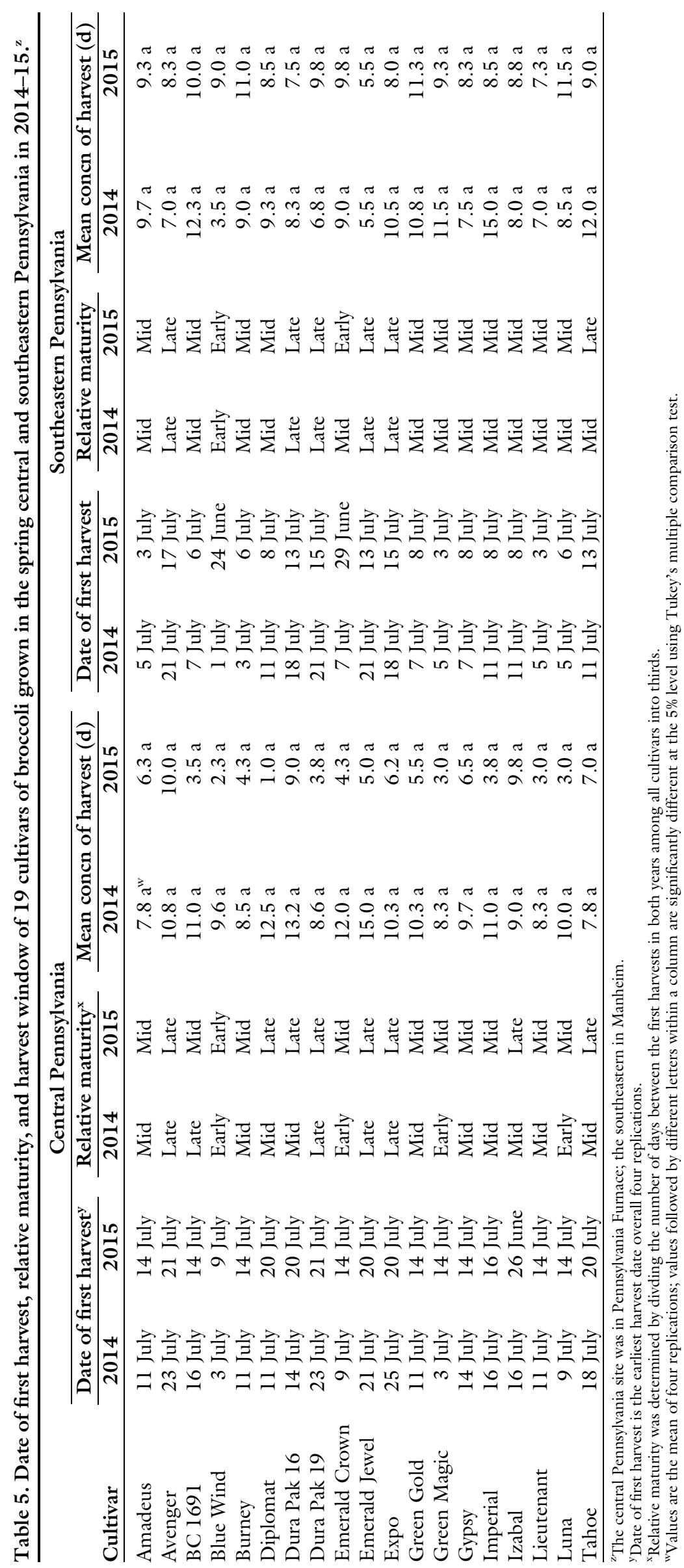




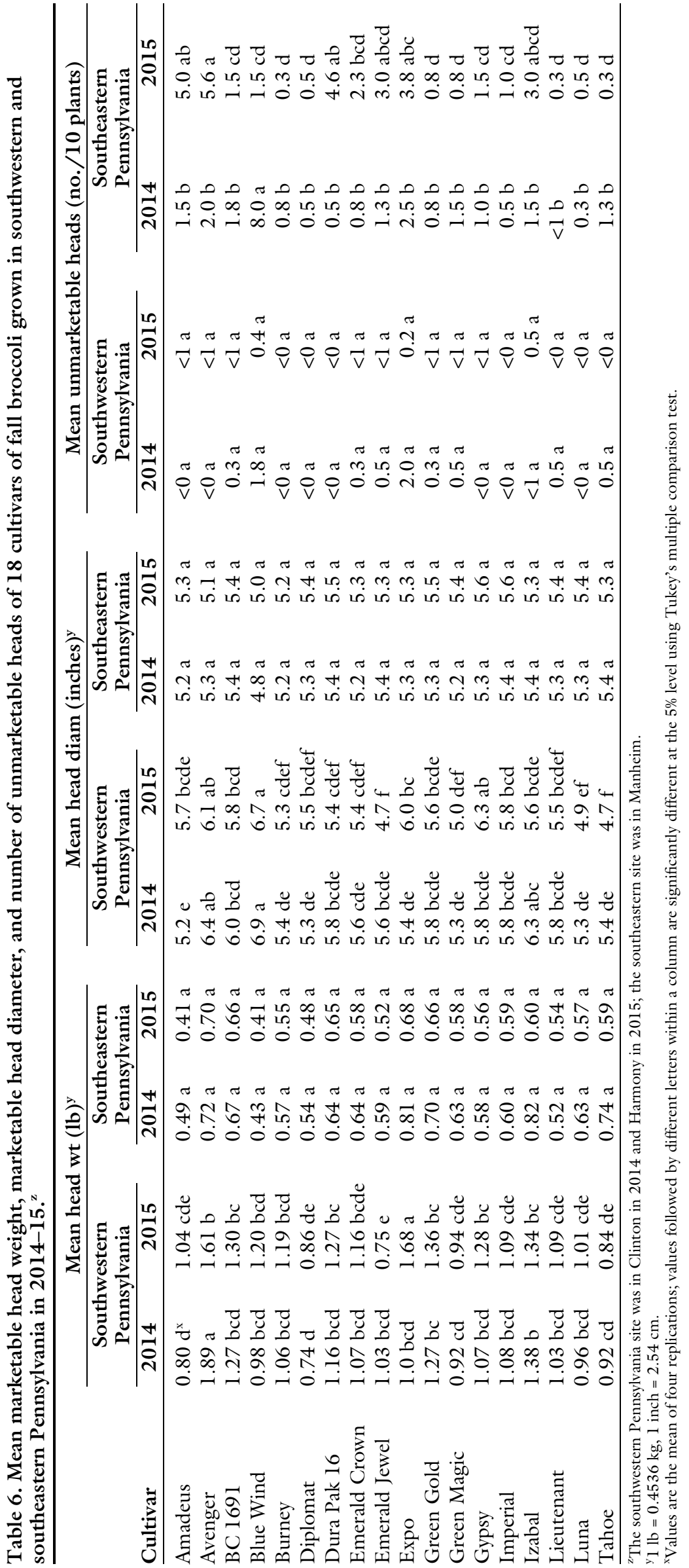

which was not different from all other cultivars within a year at the southeastern site (Table 6). In 2014, at the southwestern site, 'Avenger' heads weighed more at $1.89 \mathrm{lb}$. In 2015, 'Avenger' and 'Expo' heads weighed more at 1.61 and $1.68 \mathrm{lb}$, respectively. In addition at the southwestern site, 'Avenger' consistently produced heavier heads than 'Imperial'. At the southwest site, cultivars that produced the least heavy heads included Diplomat, Green Magic, and Tahoe.

Mean diameter of 'Imperial' heads was between 5.4 and 5.8 inches, which was not different from all other cultivars within a year at the southeastern site (Table 6). In 2014 and 2015 , at the southwestern site, 'Blue Wind' heads were larger in diameter, 6.9 and 6.7 inches, respectively. In 2015, 'Luna', 'Emerald Jewel', and 'Tahoe' heads were smaller, 4.9, 4.7, and 4.7 inches, respectively.

Mean number of unmarketable (out of 10) 'Imperial' heads was 0 to 1.0, which was not different for all other cultivars within a year for the southwestern site (Table 6). In 2014, at the southeastern site, 'Blue Wind' produced more unmarketable heads at 8.0. In 2015 , at the southeastern site, 'Avenger', 'Amadeus', and 'Dura Pakl6' produced more unmarketable heads with 5.6, 5.0, and 4.6, respectively.

In 2014 , at the southwestern site, the mean concentration of harvest ranged from 3.5 to $10.3 \mathrm{~d}$. (Table 7). 'Blue Wind' and 'Dura Pak 16' had a shorter harvest window than 'BC 1691'. All other cultivars were not different from each other. In 2015, at the southwestern site, harvest lasted 2.5 to $10.0 \mathrm{~d}$, depending on cultivar and was not different between cultivars. In 2014, at the southeastern site, harvest occurred for 5.0 to $17.0 \mathrm{~d}$, depending on cultivar. 'Blue Wind' had a shorter harvest window than 'Expo', 'Avenger', 'Burney', 'Tahoe', and 'Green Magic'. All other cultivars were not different from each other. In 2015 , at the southeastern site, harvest occurred for 3.8 to $14.0 \mathrm{~d}$, depending on cultivar. 'Amadeus', 'Green Gold', 'Burney', 'Luna', 'Blue Wind', 'Green Magic', 'Diplomat', 'Gypsy', and 'BC 1691' had shorter harvest windows than 'Avenger'. All other cultivars were not different from each other. 'Blue Wind' was consistently the earliest to reach maturity in both years and sites relative to the other cultivars, whereas 'Avenger' and 'Emerald Jewel' consistently were late in the harvest season. 


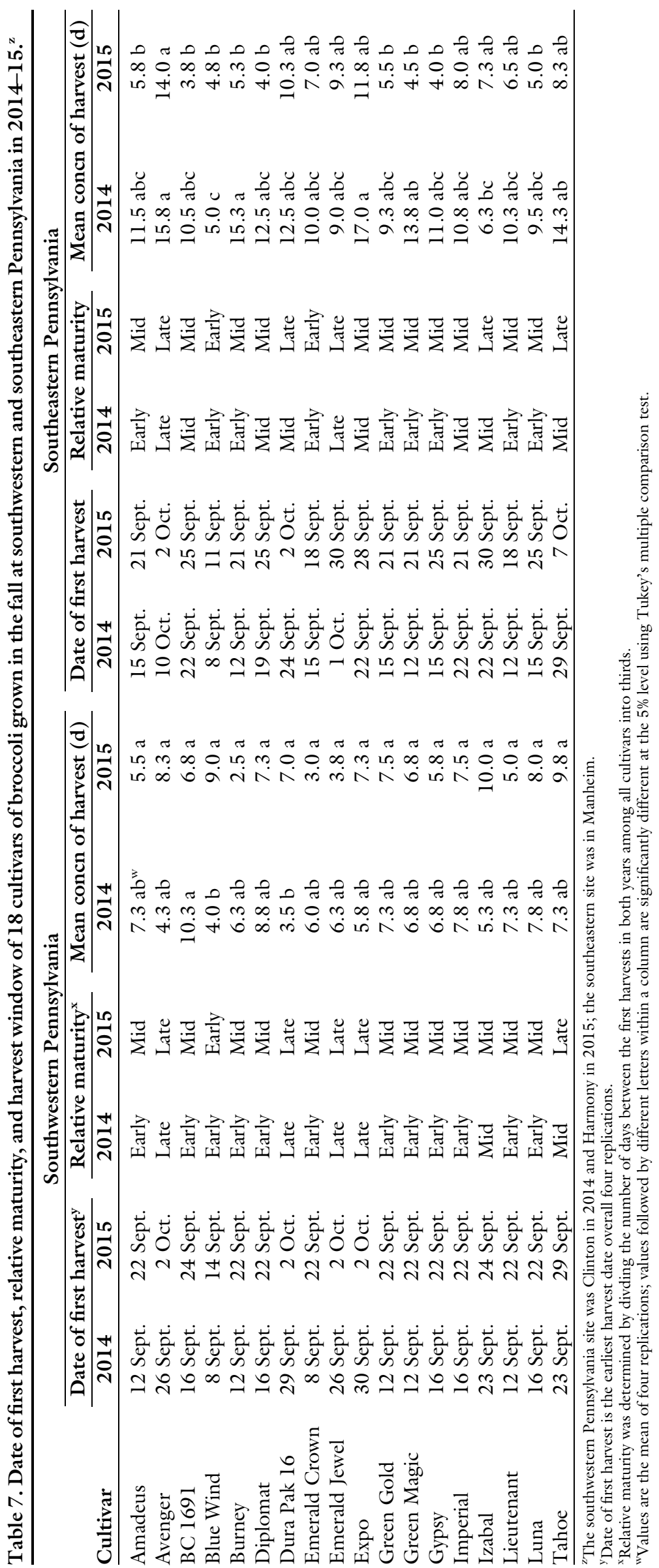

\section{Discussion}

When using bare ground or plasticulture systems with drip irrigation as used in this study, following pest management recommendations, and harvesting as heads reach maturity, growers can expect most cultivars to have similar head weights, regardless of production system and spring or fall growing season. 'Gypsy' and 'Emerald Crown' were common cultivars in two studies involving fall broccoli conducted in South Carolina (Farnham and Björkman, 2011b; Ward et al., 2015). 'Gypsy' was grown in a bare ground system with raised beds spaced $102 \mathrm{~cm}$ apart with a single row of plants spaced $15 \mathrm{~cm}$ apart for a population of about 25,000 plants/acre (Farnham and Björkman, 2011b). Mean individual head weight was between 0.45 and $0.58 \mathrm{lb}$. In our fall study, mean head weight was 1.07 and $1.28 \mathrm{lb}$ in the southwestern site and 0.58 and 0.56 in the southeastern site, both using plant populations between 6,800 and 17,000 per acre and cutting stems to 5 inches long. 'Emerald Crown' was part of a study evaluating plant density (Ward et al., 2015) and was planted in a plasticulture system using white 1-mm polyethylene mulch with populations of $43,724,29,149$, or 21,862 plants/acre. Mean individual head weight for the 29,149 population, which optimized head quality, was 0.48 to $0.63 \mathrm{lb}$. In our fall study, mean head weight was 1.07 and $1.16 \mathrm{lb}$ at the southwestern site and 0.64 and $0.58 \mathrm{lb}$ at the southeastern site. In both South Carolina studies, heads were harvested at between 4 and 5 inches diameter wide and stems were cut 6.4 inches long from the top of the head. In the present study, while mean head weights at the southeastern site are comparable to those in both South Carolina studies, stem length was shorter in 2015 . Length was possibly shorter in 2014; however, it was measured from the base of the head, making a direct comparison difficult. In addition, head diameter was generally over 5 inches indicating that heads were larger.

Higher plant populations can result in higher total yield (Ward et al., 2015). However, head and/or stem diameter was negatively correlated to plant population (Sterrett et al., 1991) or not dependent on plant population (Ward et al., 2015) likely due to cultivar and plant population used. A higher plant population than used in 
this study could be used in the midAtlantic region for markets where smaller heads are preferred.

USDA standards for broccoli specify crown head diameter for U.S. Fancy grades at 2.5 to 5 inches (USDA, 2016). Crown head diameter for other grades is left to be specified by the customer. Customer preference varies considerably in Pennsylvania. For example, one large broccoli grower in the northeastern part of the state wholesales broccoli with 2.5 to 5 inches diameters, diameters of 5 to 6 inches are found in a produce auction in the central part of the state, and in areas of the southwestern part of the state direct-marketed broccoli is sold at "dinner plate" diameters (8 to 9 inches).

Concentrated harvest can be important for markets where once-over harvest is desired. The cultivars evaluated in this study were not different from 'Imperial' in any site year. In addition, none were different from each other for the spring crop. For the fall crop, for three site years, a few differences in length of harvest existed; however, none with any consistency. Harvesting broccoli for markets where even a small range in head diameter is acceptable allows some flexibility in determining when to harvest. One has the option to harvest anytime between the minimum or maximum size, which can be a few days different. In this study, mean head diameter ranged from 2.3 to 5.6 inches for the spring crop and 4.7 to 6.9 inches for the fall crop. Had harvest been set at one fixed size or occurred on a single date instead of multiple dates, differences in the concentration of harvest may have resulted.

Relative maturity is another important factor for growers to extend the harvest and therefore marketing season. 'Blue Wind' was consistently the first cultivar harvested overall site years and growing seasons. At the central site in 2015 , the spring broccoli planting was diseased with alternaria leafspot and head rot (caused by Alternaria brassicicola and Alternaria brassicae). 'Blue Wind' was at a harvestable stage when the disease was discovered and a high number of unmarketable heads of this cultivar resulted. Chlorothalonil was applied at a rate of $1.5 \mathrm{pt} / \mathrm{acre}$ a.i. (Bravo Weather Stik; Syngenta Crop Protection, Wilmington, DE) that protected all other cultivars from the disease. Particularly for a spring broccoli crop, early maturing is otherwise a favorable attribute to avoid temperatures above $86^{\circ} \mathrm{F}$, which cause head deformity (Björkman and Pearson, 1998) rendering them unsaleable.

Avenger and Emerald Jewel were consistently late-season cultivars over the four site years. These two cultivars along with Blue Wind may be good options for extending the growing season. 'Blue Wind' heads had a blue tinge to them in contrast to the more typical green associated with broccoli which should be considered, depending on consumer preference. Appearance is a key quality factor for customer preference of broccoli. Sensory analysis observed that broccoli appearance was the critical factor for consumer acceptance, more important than flavor and aroma, in postharvest shelf life (Garitta et al., 2013).

Eighteen or 19 commercially available broccoli cultivars were evaluated over two seasons and years, at three sites and using varying production systems. Although many interactions were present, overall the cultivars were not different from Imperial (considered the standard cultivar for the region) for marketable yield, head diameter, and concentration of harvest within a site year. Using a higher plant population can result in higher yields; however, head size may be smaller than observed in this study. Market demand for size should be considered when determining plant populations. Although the date of first harvest was different for many cultivars, the concentration of harvest was not consistently different from 'Imperial'. In the mid-Atlantic region, commercial broccoli growers have many good commercially available cultivar options for spring and fall crops.

\section{Literature cited}

Atallah, S.A., M. Gomez, and T. Björkman. 2012. Eastern broccoli supply chain model. 20 Apr. 2016. <http://www.hort.cornell. edu/bjorkman/lab/broccoli/Reports/ ASHSPoster2012supply_chain.pdf $>$.

Björkman, T. and K.J. Pearson. 1998. High temperature arrest of inflorescence development in broccoli (Brassica oleracea var. italica L.). J. Expt. Bot. 49:101-106.

Farnham, M.W. and T. Björkman. 2011 a. Breeding vegetables adapted to high temperatures: A case study with broccoli. HortScience 46:1093-1097.

Farnham, M.W. and T. Björkman. 2011b. Evaluation of experimental broccoli hybrids developed for summer production in the eastern United States. HortScience 46:858-863.

Garitta, L., G. Hough, and A. Chaves. 2013. Sensory analysis of broccoli over time: Consumer defined critical attributes and evaluation of digital photographs in comparison to real product appearance. Food Qual. Prefer. 29:48-52.

Kuhar, T.P., G.C. Hamilton, M.J. VanGessel, E. Sánchez, A. Wyenandt, and D. Dugan (eds.). 2016. 2016 Mid-Atlantic commercial vegetable production recommendations. Penn State Ext. Publ. AGRS-028.

Low, S.A., A. Adalja, E. Beaulieu, N. Key, S. Martinez, A. Melton, A. Perez, K. Ralston, H. Stewart, S. Suttles, S. Vogel, and B.B.R. Jablonski. 2015. Trends in U.S. local and regional food systems. U.S. Dept. Agr., Econ. Res. Serv. AP-068.

Maynard, D.N. and G.J. Hochmuth. 2007. Knott's handbook for vegetable growers. 5th ed. Wiley, Hoboken, NJ.

Mukherjee, S. and D.K. Das. 2009. Health benefits of broccoli. Acta Hort. 841:181-186.

Sánchez, E., T. Elkner, W.J. Lamont, K. Demchak, B.K. Gugino, S.J. Fleischer, K. Watrous, L. LaBorde, and K. HoffmanRichards. 2015. Commercial vegetable production recommendations. Penn State Ext. Publ. AGRS-028.

Sánchez, E., T. Elkner, W.J. Lamont, K. Demchak, M.D. Orzolek, B.K. Gugino, J. M. Halbrendt, S.J. Fleischer, L. LaBorde, K. Hoffman, and G.J. San Julian. 2014. Commercial vegetable production recommendations. Penn State Ext. Publ. AGRS-028.

Sterrett, S.B., C.W. Coale, and C.P. Savage. 1991. Comparison of management techniques for broccoli production using a systems approach. HortScience 26:599-602.

U.S. Department of Agriculture (USDA). 2011. U.S. broccoli statistics, Table 7. 14 Apr. 2016. <http://usda.mannlib.cornell. edu/MannUsda/viewDocumentInfo.do? documentID=1816>.

U.S. Department of Agriculture (USDA). 2014. Agricultural statistics data base, state level data for vegetables and melons, fresh and processed. 21 Mar. 2016. <http:// www.agcensus.usda.gov/Publications/ 2012/Full_Report/Volume_1,_Chapter_ 1_US/usvl.pdf>.

U.S. Department of Agriculture (USDA) 2016. Broccoli information sheet. 30 Mar. 2016. <http://www.nfsmi.org/documentlibraryfiles/ PDF/20160314111102.pdfs.

Ward, B., P. Smith, S. James, Z. Stansell, and M. Farnham. 2015. Increasing plant density in eastern United States broccoli production systems to maximize marketable head yields. HortTechnology 25:330-334. 